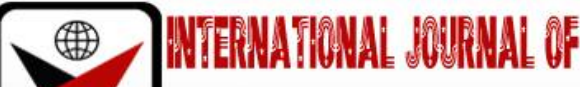

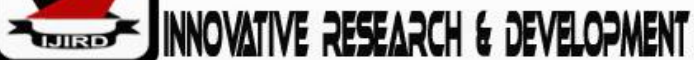

ISSN 2278-0211 (Online)

\section{Microbial Profile and Physicochemical Composition of Yellow and White Garri Sold in Different Markets}

\author{
Dr. Nnenna Omorodion \\ Lecturer, Department of Microbiology, University of Port Harcourt, River State, Nigeria \\ Josephine Chijor \\ Student, Department of Microbiology, University of Port Harcourt, River State, Nigeria
}

\begin{abstract}
s:
Garri which is an important source of energy and fibre contains proteins and some essential vitamins and is particularly popular because of its ready-to-eat nature. A total of 16 samples of white and yellow garri were assessed and standard microbiological methods were used. The white garri samples obtained from the four markets had the highest heterotrophic bacteria count ranging from $8.9 \times 10^{-6} \mathrm{cfu} / \mathrm{g}$ (Rumokoro market) to $9.8 \times 10^{-6} \mathrm{cfu} / \mathrm{g}$ (Alakahia market).

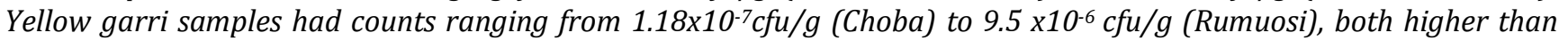
the W.H.O directives on microbial limits of foods which states that THBC $\leq 5.0 \times 10^{5}$ colonies/gram of sample. White garri samples (Alakahia) had the lowest fungal count that ranged from $3.2 \times 10^{4} \mathrm{cfu} / \mathrm{g}$ to $5.05 \times 10^{4} \mathrm{cfu} / \mathrm{g}$ and yellow garri, 5.1 $1 \times 10^{4} \mathrm{cfu} / \mathrm{g}$ (Rumuosi) to $8.0 \times 10^{4} \mathrm{cfu} / \mathrm{g}$ (Choba). Bacterial and Fungi isolates obtained from the garri samples which were isolated and identified during this study include Staphyloccocus aureus, Staphylococcus epidermidis, Escherichia coli, Micrococcus sp., Bacillus sp. and Klebsiella sp. Aspergillus niger, Aspergillus flavus, Candida sp., Saccharomyces sp. and Penicillum sp., Geotrichium sp., Fusarium sp. respectively. The result obtained from the proximate analysis carried out on both garri samples showed that yellow garri sample had a lower carbohydrate content of $72.22 \%$ than white garri sample which was $72.45 \%$. Hence, it is recommended that garri should be stored in sack bags or air tight containers in the markets to avoid contamination. Regulatory agencies should be set up at strategic market places to ensure the enforcement of microbiological safety of garri by providing trainings on safety criteria, safe handling technique and microbiological limits of garri.
\end{abstract}

Keywords: White garri, yellow garri, pathogen, market

\section{Introduction}

Garri is the most popular form in which cassava is consumed by several millions of people in the African continent especially in the West Africa Sub Region (Ogiehor, 2002). Regardless of ethnicity and socio-economic class, it is the most common meal amongst the rich and the poor. Nigeria is the current leading cassava (Manihot esculenta Crantz) producing country in the world, but almost all the cassava produced are used for human consumption with less than $5 \%$ used in industries (FAO, 2002; Ajao and Adegun, 2009).

Garri is a roasted granular hygroscopic white or yellowish starchy food product, it is a dehydrated staple food with a high swelling capability and can absorb up to four times its volume in water. To prepare this food, fresh cassava roots are peeled, washed and grated. The resultant pulp is put in a porous sack (poly propylene bag) and weighed down with a heavy object or hydraulic press while it is fermenting. The dewatered and fermented lump of the pulp is pulverized, sifted and the resulting semidried mash is toasted in a pan (Nweke et al., 2002). The final granulated product may be white or yellowish product as the colour depends on production methods used.

Garri is an important source of energy and fibre and is particularly popular because of its ready-to-eat nature. It is classified/ grouped based on texture, length of fermentation, region or place where it is produced and colour imparted by the addition/ non-addition of palm oil. (Jekayinfa and Olajide, 2007). Garri is rich in starch. It is also having a very high fibre content and contains proteins and some essential vitamins. The high fibre content in garri makes it very filling, and also makes it good in preventing and/or reducing the likelihood of constipation and bowel upsets. Garri available in the market can be consumed directly without cooking by soaking in water without or with a variety of additives such as sugar, groundnut, fish, meat and stew, coconut, akara, milk prior to consumption or processed minimally using boiled water to form a stiff paste popularly called 'eba' and eaten with various types of African soups. (Ajao and Adegun, 2009).

There are different types of garri, depending on how it is processed and the region of Africa where it is produced. Red garri (Bendelgarri) is commonly found in the mid-Western part of Nigeria. Ijebu garri is made in the western part of Nigeria and is found great for 'soaking. Ghana garri as the name implies is garri made in Ghana. Ghana garri is starchy, very crispy and lasts very long in storage.

Garri is displayed and sold in the market in open basins, bowls and trays and on mats spread on the floor or on tables which potentiate contamination by various groups of microorganisms and may predispose public health hazards. 
Various groups of moulds which include Aspergillus niger, Aspergillus flavus, Candida sp., Saccharomyces sp. and Penicillum sp., Geotrichium sp., Fusarium sp have been reported to be associated with garri as well as other microorganisms such as Staphyloccocus aureus, Staphylococcus epidermidis, Escherichia coli, Micrococcus sp., Bacillus sp. and klebsiella sp. during storage and distribution which if present can grow and affect the nutritional and sensory properties of the garri. The garri is stored in exposed basins and large sack bags in stores at the market place or in the homes and transferred to the market when needed. Due to the mode of sampling and sales, in the market aerial microorganisms can be deposited on the exposed garri either by active or passive mechanisms. In active mechanism, the bursting of ascus after absorbing water at a high pressure and releasing its spores could fall on the exposed garri. In passive mechanism, the organisms could be carried by wind and deposited on the exposed garri or by rain splash.

Garri production is laborious and cumbersome and production methods vary from one locality to another resulting in products of non-uniform quality. However, the practices that are associated with its production, processing and post processing handling of garri such as spreading on the floor, mats, display in open bowl in the markets, sale points, and use of various packaging materials to haul finished products from rural to urban areas may exacerbate microbial contamination (Ogiehor and Ikenebomeh, 2006). Markets that are close to waste sites and rivers where faeces are disposed, aerial contamination could also be a major problem as the air around such vicinity may be laden with coliforms emanating from such disposed organic matter. The microbial contaminants of garri result in serious health effects such as liver, cancer, kidney damage, typhoid, apergillosis, asthma and hypersensitivity and may serve as a source of food borne diseases (Islam et al., 1993; Maria et al., 2001; Venugopal, 2001, Omar et al.,2003). Information needed on what type of garri in respect to colour (white or yellow) is preferable in terms of microbial load and physicochemical parameters; and providing useful information as regards the public health concerns of the different brands of garri are the reasons why this study was carried out. The objective of the study is to determine the growth of microorganisms in different brands of garri in Rivers State and to evaluate the proximate composition and physicochemical parameters of the different brands of garri, to identify the pathogens of public health concern present in different brands of garri and finally to proffer solutions for proper handling and sales of garri in markets

\section{Materials and Method}

\subsection{Area of Study}

The garri used for this study were obtained from four different markets in Port Harcourt municipality. These samples obtained were from different sellers who sold garri in exposed basins and were transported to the lab in Ziploc bags and sampled within $24 \mathrm{hrs}$.

\begin{tabular}{|c|l|l|}
\hline Market & \multicolumn{1}{|c|}{ Location } & \multicolumn{1}{|c|}{ Remarks } \\
\hline Choba & $\begin{array}{l}1 \mathrm{~km} \text { from the University of Port } \\
\text { Harcourt } \\
\text { Alakahia }\end{array}$ & $\begin{array}{l}\text { Situated near a poor drainage site with } \\
\text { refuse dump close by and a park. } \\
\text { Situated in an unhygienic environment }\end{array}$ \\
Rumuosi & $\begin{array}{l}\text { Harcourt } \\
2 \mathrm{~km} \text { from the University of Port } \\
\text { Harcourt } \\
\text { Rumuokoro 4km from the University of } \\
\text { Port Harcourt }\end{array}$ & $\begin{array}{l}\text { Situated near an express road. The } \\
\text { environment is unhygienic } \\
\text { Situated in a dusty and dirty environment } \\
\text { by a park and a busy express road. }\end{array}$ \\
\hline
\end{tabular}

Table 1: Markets Sampled and Their Location

\subsection{Sample Collection}

A total of 16garri samples used for this research were purchased randomly from different markets (Choba, Rumukoro, Alakahia and Rumuosi markets). The samples were collected aseptically into sterile polyethylene bags and were transported to the laboratory for analysis within two hours of collection. Samples were categorized according to the location of purchase Microbiological analysis of the different brands of the garri samples

Ten (10) grams of each garri samples were weighed into a beaker containing $90 \mathrm{ml}$ of sterile peptone water and allowed to stand for 5 minutes with occasional stirring using a sterile glass rod. From the supernatant, ten-fold serial dilution was carried out by transferring $1 \mathrm{ml}$ from the supernatant into $9 \mathrm{ml}$ sterile diluents. To obtain dilution 10-2, this was repeated into $9 \mathrm{ml}$ diluents to obtain dilution $10-3$, the process was repeated till dilution $10-5$ was obtained. $0.1 \mathrm{ml} 10$ 4-10-5 of each dilution was dispersed into the Plate count agar in duplicates while $0.1 \mathrm{ml}$ of $10-2-10-3$ into the selective media. Commercially made media were used for isolation, identification and characterization of microorganisms. The media used include: Nutrient agar, Manitol Salt agar, MacConkey agar, Potato dextrose agar. All media, diluents and glass wares used (Petri plates, bijou bottles, test tubes, pipette) were sterilized by autoclaving at 121 oC for $15 \mathrm{mintues}$ at 15 psi, unless stated otherwise

\subsection{Isolation of Microorganisms}

From the aliquot, $0.1 \mathrm{ml}$ was plated onto nutrient agar using spread plate method for total viable heterotrophic count, mannitol salt agar for Staphylococcus count, MacConkey agar for coliform count and the plates were incubated at $37^{\circ} \mathrm{C}$ for $24 \mathrm{hrs}$. For total fungi count, $0.1 \mathrm{ml}$ of the diluent was plated onto potato dextrose agar (PDA) and incubated at $26^{\circ} \mathrm{C}$ for 2-5 days. 


\subsection{Purification of Isolates}

Single colonies of bacteria were randomly picked from the different bacteriological media previously incubated based on their morphological characteristics and were sub cultured on freshly prepared media and incubated for $24 \mathrm{hrs}$ at $37^{\circ} \mathrm{C}$ to obtain a pure culture. After the purification of isolates, nutrient agar slants were prepared in bijou bottles by dispensing $10 \mathrm{ml}$ of the nutrient agar into bijou bottles and autoclaved at $121^{\circ} \mathrm{C}$ for $15 \mathrm{~min}$ at $15 \mathrm{psi}$, slanted and allowed to solidify. After which a sterile wire loop as used to pick each inoculum and streaked onto the surface of the slanted nutrient agar and stabbed into the butt and incubated at $37^{\circ} \mathrm{C}$ for 24 hours.

\subsection{Identification and Characterization of Isolates}

Bacterial Isolates were identified based on their morphological and cultural characteristics on growth media which includes colony size, colour, opacity, consistency, colony pigmentation, elevation, odour, swarming), identification materials, reagents and protocols according to (Chessebrough, 2005)

Fungal isolates were done based on the colonial morphology (colour, size, texture) and the cell morphology (mycelia, hyphae) of the fungi was done using lactophenol blue. A piece of the mycelium from the Petri dishes was mounted on a clean grease free slide using a sterile wire loop and covered with a cover slip and a drop of lactophenol cotton blue was added and allowed for few minutes before examining with the microscope.

\subsection{Physicochemical Parameters}

\subsubsection{Determination Of $\mathrm{pH}$}

The $\mathrm{pH}$ of the samples was determined following the procedures described by Ogiehor and Ikenebomeh (2005). $10 \mathrm{~g}$ of each sample were homogenized in $10 \mathrm{ml}$ of distilled water in a beaker. The $\mathrm{pH}$ was determined by using a reference glass electrode $\mathrm{pH}$ meter.

\subsubsection{Determination of Loose Density}

This was calculated by weighing $10 \mathrm{~g}$ of garri sample into a measuring cylinder without tapping and noting the final volume occupied.

\subsubsection{Determination of Bulk Density}

This was done by tapping the measuring cylinder containing the $10 \mathrm{~g}$ of garri sample from the loose density determination on a table and noting the stable final volume.

\subsection{Determination of Swelling Index}

This was done as described by Ukpabi and Ndimele (1990). 50g each of garri samples were put into a $500 \mathrm{ml}$ measuring cylinder. $300 \mathrm{ml}$ of water was added to the garri sample and allowed to stand for 4 hours. The level of swelling was noted and the swelling index was calculated as the multiple of the original volume.

PROXIMATE ANALYSIS This was done as described Okoli et al.,2012

\section{Result}

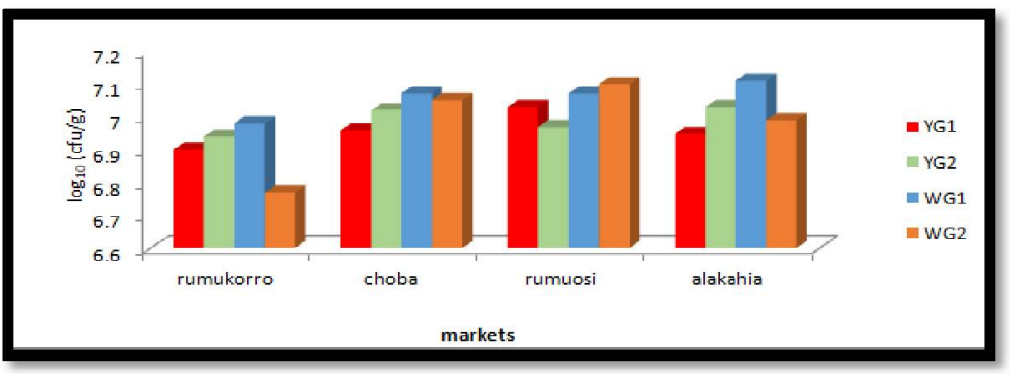

Figure 1: Total Heterotrophic Bacterial Count from Garri Samples Obtained from Different Markets Legend; YG-Yellow Garri, WG-White Garri

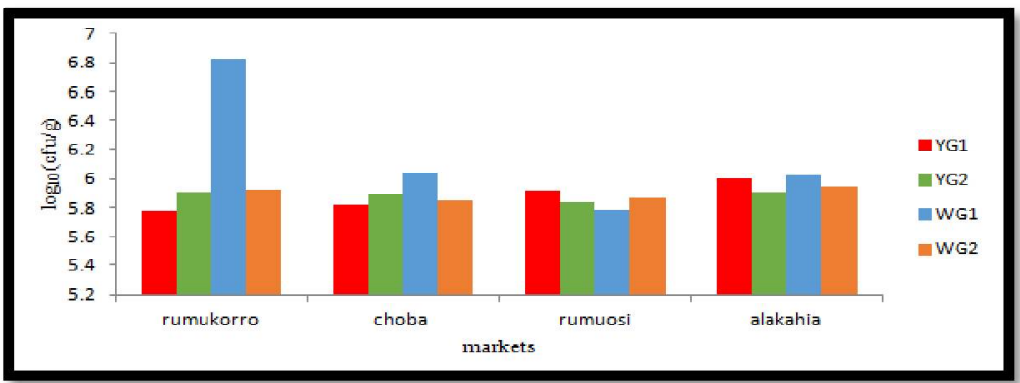

Figure 2: Total Staphylococcus Count from Garri Samples Obtained from Different Markets Legend; YG-Yellow Garri, WG-White Garri 


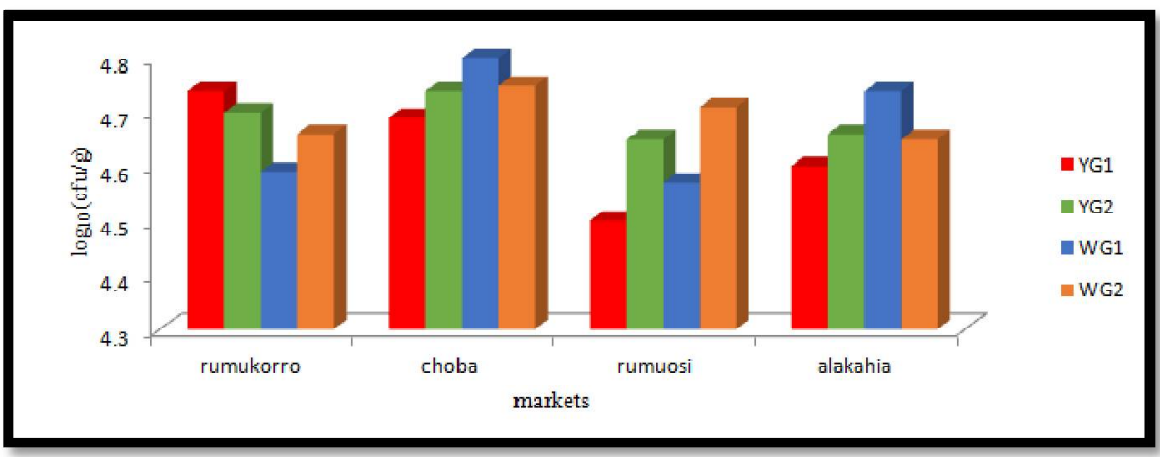

Figure 3: Total Coliform Count from Garri Samples Obtained from Different Markets Legend; YG-Yellow Garri, WG-White Garri

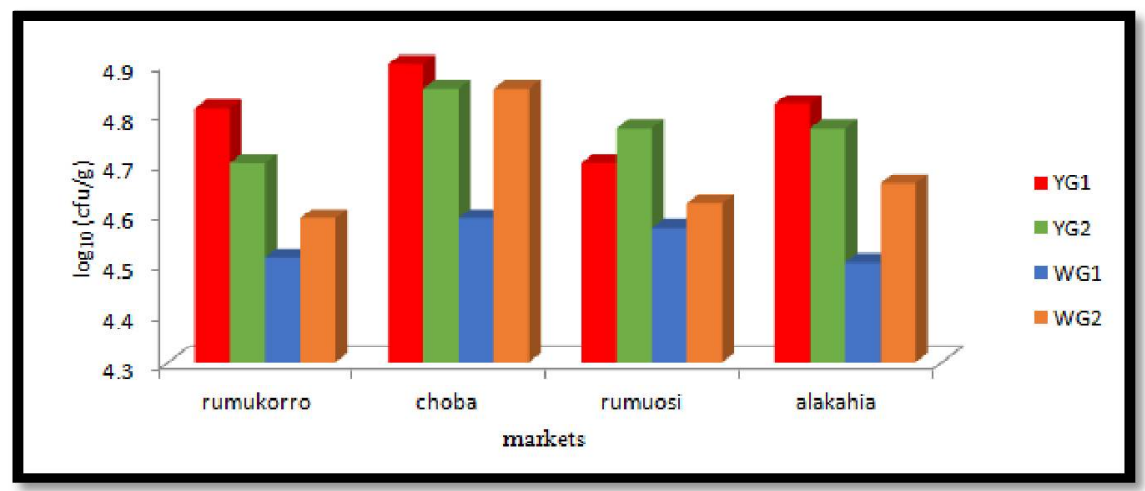

Figure 4: Total Heterotrophic Fungal Count from Garri Samples Obtained from Different Markets, Legend; YG-Yellow Garri, WG-White Garri

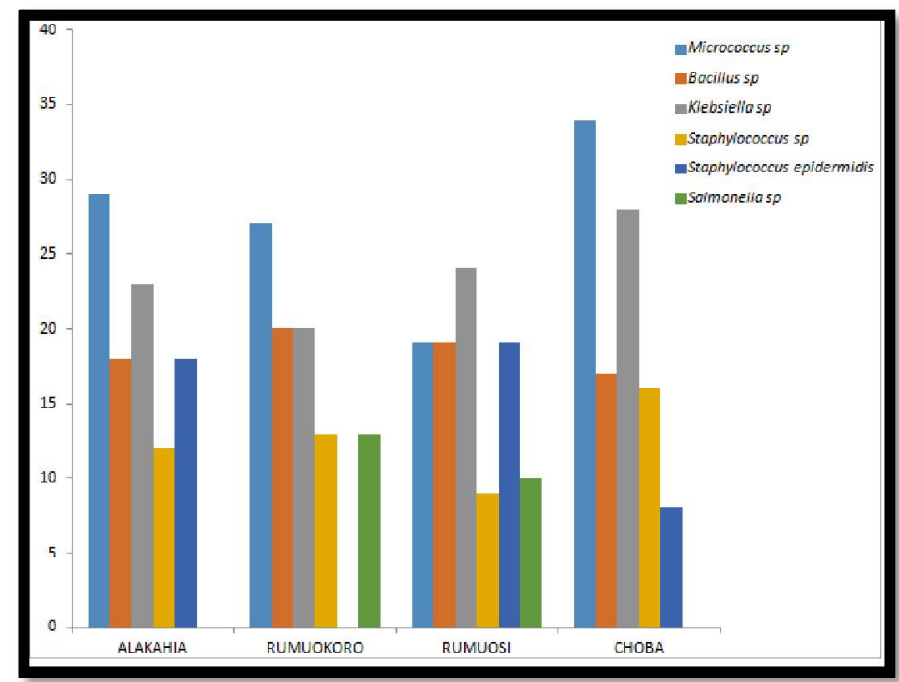

Figure 6: Showing the Frequency of Occurrence of the Different Pathogens Found In the Garri Samples

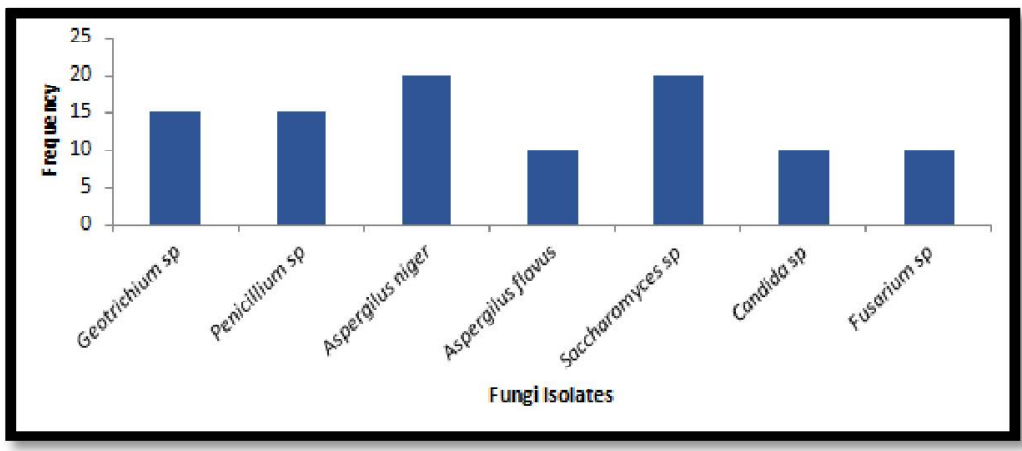

Figure 6: Frequency of Occurrence of Fungi Isolated from Garri Samples Obtained from All Four Markets 


\begin{tabular}{|c|c|c|c|c|}
\hline S/no & Sample area & pH & Loose density (m) & Bulk density (m) \\
\hline 1 & RKY1 & 5.9 & 16 & 14 \\
\hline 2 & RKW1 & 4.6 & 12 & 10 \\
\hline 3 & RKY2 & 4.9 & 15.5 & 13 \\
\hline 4 & RKW2 & 4.8 & 14 & 12 \\
\hline 5 & AY1 & 6.1 & 18 & 15 \\
\hline 6 & AW1 & 4.7 & 16 & 13 \\
\hline 7 & AY2 & 5.5 & 14.5 & 15 \\
\hline 8 & AW2 & 4.6 & 17 & 10 \\
\hline 9 & CY1 & 5.1 & 12 & 8 \\
\hline 10 & CW1 & 5.3 & 10 & 16 \\
\hline 11 & CY2 & 5.2 & 10 & 10 \\
\hline 12 & CW2 & 4.5 & 17 & 10 \\
\hline 13 & RSY1 & 4.9 & 14 & 8 \\
\hline 14 & RSW1 & 4.7 & 12 & 10 \\
\hline 15 & RSY2 & 5.1 & 14 & \\
\hline 16 & RSW2 & 4.8 & 12 & \\
\hline
\end{tabular}

Table 2; Physicochemical Parameters of the Different Garri Samples

Keys: Rky = Yellow Garri (Rumukoro Market), Rkw= White Garri (Rumukoro Market)

Ay= Yellow Garri (Alakahia Market, Aw= White Garri (Alakahia Market)

Rsy= Yellow Garri (Rumuosi Market), Rsw= White Garri (Rumuosi Market)

Cy= Yellow Garri (Choba Market), Cw= White Garri (Choba Market)

\begin{tabular}{|l|l|l|l|}
\hline \multirow{2}{*}{$\mathbf{S} \backslash \mathbf{N}$} & \multirow{2}{*}{$\begin{array}{c}\text { Proximate } \\
\text { composition }\end{array}$} & \multicolumn{2}{c|}{ Garri samples (\%) } \\
\cline { 3 - 4 } & & \multicolumn{2}{|c|}{$\begin{array}{c}\text { White garri } \\
\text { yellow garri }\end{array}$} \\
\hline 1 & Carbohydrate & 72.45 & 72.22 \\
\hline 2 & Protein & 1.7 & 1.75 \\
\hline 3 & Lipid & 1.48 & 1.56 \\
\hline 4 & Ash & 1.7 & 1.3 \\
\hline 5 & Moisture Content & 11.87 & 12.27 \\
\hline 6 & Crude Fibre & 10.8 & 10.9 \\
\hline
\end{tabular}

Table 3: Proximate Composition of the Garri Samples

\section{Discussion}

From this study it is clear that garri samples (both yellow and white garri) harbour arrays of bacterial and fungal contaminants. The total heterotrophic bacteria count of the garri samples shown in Table 2 indicates that the white garri samples obtained from the four markets had the highest heterotrophic bacteria count which ranged from 8.9x10-6 cfu/g (Rumokoro market) to 9.8x10-6cfu/g (Alakahia market) than that of yellow garri samples with counts which ranged from $1.18 \times 10-7 \mathrm{cfu} / \mathrm{g}$ for (Choba market) to $9.5 \times 10-6 \mathrm{cfu} / \mathrm{g}$ for (Rumuosi market). The findings of this study are higher than the findings of total heterotrophic count of fermented cassava flour obtained by Ijabadeniyi, (2007) who reported $1.5 \times$ $106 \mathrm{cfu} / \mathrm{g}$ and that of Tsau-Wau, 2004 who reported $1.2 \times 107 \mathrm{cfu} / \mathrm{g}$ to $2.7 \times 103 \mathrm{cfu} / \mathrm{g}$ but were close to the count reported by some other researchers. It is also higher than the World Health Organization directives on microbial limits which states that Total Heterotrophic Bacterial Count should not exceed $5.0 \times 105$ colonies per gram of sample and coliform count should not exceed $5.0 \times 103$ colonies per gram of sample which from this study, some of the results were higher and the others were within the limit with white garri sample from (Choba market) having the highest count of $6.4 \times 104 \mathrm{cfu} / \mathrm{g}$ followed by that of Rumuosi market 3.84x104 cfu/g and yellow garri samples count were $5.6 \times 104 \mathrm{cfu} / \mathrm{g}$ and 3.55 x104 $\mathrm{cfu/g}$ for (Rumukoro market) for (Rumuosi market) respectively for coliform.

These findings however revealed that the THBC ranged from $1.06 \times 107 \mathrm{cfu} / \mathrm{g}-9.8 \times 106 \mathrm{cfu} / \mathrm{g}$. Some of the microbial counts obtained from this study conformed to the microbiological limit showing partial negligence on the part of National agencies concerned with food inspection in the country.

The total Staphylococcus count of the garri samples is shown in Table 3. Food and Drug Agency (FDA) limit for Staphylococcus in foods is $<105 \mathrm{CFU} / \mathrm{g}$. The lowest Staphylococcus count was recorded for yellow garri samples, with bacteria counts that ranged from 1.00x10-6 cfu/g (Alakahia market) to 5.9x10-5 cfu/g (Rumukoro market) which is lower than that of the white garri samples which had counts that ranged from $6.1 \times 10-5 \mathrm{cfu} / \mathrm{g}$ for (Rumuosi market) to $6.75 \times 10-6$ $\mathrm{cfu} / \mathrm{g}$ for (Rumukoro market). These findings are within the permissible limit of FDA but corroborate the report of Ogiehor et al, 2007.

The level of contamination by mould and bacteria recorded in this study is mainly due to contamination as a result of local method of processing (Amadi and Adebola, 2008). This is also an indication of recommendation in food handling/hygiene technique. The practices that are associated with the production, processing and post processing handling of garri such as spreading on the floor, mat and the open display in bowls and basins in the market, measurement with the aids of bare hands, coughing and sneezing while selling and also the use of non-microbiologically determined 
hessian bags for packaging and haulage may be responsible for its contamination as the growth of these microorganisms in the food results to changes in the organoleptic, microbiological and nutritive quality which subsequently results in spoilage. (Ogeihor and Ikenebomeh, 2005),

Data obtained on the analyses of the garri samples obtained at the four markets for bacterial contaminants include seven different bacterial genera with their highest percentage of occurrence: Bacillus sp. 20\%, Staphylococcus aureus 16\%, Staphylococcus epidermidis 19\%, Micrococcus sp. 34\%, Salmonella sp. 13\%, Escherichia coli 7\% and Klebsiella sp. $28 \%$. The isolation of Staphylococcus aureus is of human origin and their presence could be from handlers, intrinsic and the environment. It has been known to cause various pus-forming infections in humans such as boils, carbuncles, impetigo, osteomyelitis, toxic shock syndromes. (Hartman et al., 2004). On the other hand, Staphylococcus epidermidis which was also isolated from the samples is a normal flora of the skin but can occasionally assume an opportunistic pathogenic role in causing human infection such as endocarditis (Anastasiades et al., 2009). The isolation of Salmonella sp. and E. coli from garri samples obtained Choba market may be connected with its proximity to an unkempt drainage / refuse dump very close to the market as also were the findings of Oje et al., (2000.) Bacillus cereus is an environmental contaminant which was also isolated from the sample. It has been reported to be pathogenic especially if found to be present at $105-107 \mathrm{cfu} / \mathrm{g}$. (Michelet et al, 2006).

White garri samples from Alakahia market had the lowest fungal count that ranged from $3.2 \times 104 \mathrm{cfu} / \mathrm{g}$ to $5.05 \times 104 \mathrm{cfu} / \mathrm{g}$ and yellow garri fungal counts ranged from 5.1x104 cfu/g Rumuosi market to 8.0x104 cfu/g Choba market as represented in Table 5. The International Commission on Microbiological Specifications for Foods (ICMSF) states that ready to eat foods with counts of $\leq 103 \mathrm{CFU} / \mathrm{g}$ are acceptable, counts of 104-105 CFU/g are tolerable while counts of $\geq 106$ CFU/g are unacceptable (ICMSF, 1996). The average Total Fungi Count value of the garri sample is $<103 \mathrm{CFU} / \mathrm{g}$, within this range, food is safe for consumption. Therefore, we can say that the TFC of our garri sample is within the range of acceptable limit but higher than the value gotten by other researchers like Obadina et al, 2009 who reported 1.79 x104 CFU/g. The fungal contamination of the garri samples could be as a result of the deposition of bioaerosols on the exposed garri in the markets. Airborne fungal spores are released into the atmosphere by explosive discharge mechanisms that require high humidity and moisture and these spores are carried by wind and transported vertically and horizontally (Aylor, 1995; Nagarajan and Singh., 1990) and may thus, be deposited on the exposed food items in the markets. Aspergillus sp. which was the most frequently isolated fungi in both yellow and white garri samples is among the most abundant and widely distributed organisms on earth (Klich, 2002). Members of this genus are saprophytic moulds living in the environment without causing diseases (Cheesborough, 2005). Aspergillus niger has the highest occurrence in both garri samples. Penicillium sp. is an uncommon pathogen in humans and has also been reported as a common opportunistic pathogen causing systemic penicilliosis in AIDS patients in Thailand, Southern China and other parts of Southern Asia (Cheesborough, 2005). Data obtained from the analysis of the gari samples from the four markets are represented in table 2 and the frequency of each fungal isolate is shown in figure 9. These isolates include Aspergillus niger 20\%, Aspergillus flavus 10\%, Saccharomyces cerevisae 20\%, Geotrichium sp. 25\%, Fusarium sp. 10\%, Candida sp. 10\% and Penicillium sp $15 \%$.

The result obtained from the proximate analysis carried out on both garri samples shows that yellow garri sample had a lower carbohydrate content of (72.22 \%), lipid (1.56\%), protein (1.75\%), ash (1.30\%), moisture content (12.27 \%), crude fibre (10.90\%). The white garri samples had a higher carbohydrate content of (72.45 \%), lipid (1.48 \%), protein $(1.70 \%)$, ash (1.70\%), moisture content (11.87\%), and crude fibre $(10.80 \%)$. Moisture content levels of the garri samples were within standard range of $12.7-13.6 \%$. The moisture content of yellow garri was $12.27 \%$ and white garri $11.87 \%$. The low moisture content of white garri suggests longer storage lives and better cooking qualities, (Eleazu and Eleazu, 2012) The proximate composition values of the garri samples (both white and yellow) are comparable to that obtained by Oluwole et al. 2004. From the above result, there was a high significant statistical difference ( $p>0.05)$ between the two brands of garri.

For the physicochemical parameters, yellow garri had a higher swelling index than white garri. The pH's of the yellow garri samples ranged from 4.9-5.9 and were higher than that of the white garri samples which showed lower $\mathrm{pH}$ and ranged from 4.5-5.3 implying reduced level of cyanide as opposed to the observed pH and cyanide effect of white garri. The $\mathrm{pH}$ values of this study can also be comparable to that obtained by Cornelia et al (2017), whose values were 4.6 - 5.8. Yellow garri had a higher loose density of 12 - 18 than white garri which was 10 - 17, but had a lower bulk density of 8 - 15 and white garri 8-16. The loose density of garri is expected to be less than the bulk density as the bulk density method involved tapping on a hard surface which reduced the volume. The percentage moisture content of the white garri influenced the bulk density as high bulk densities imply reduced volume. (Cornelia et al, 2017)

Developing strategies to antagonize the growth and survival of microorganisms in foods in order to neutralize the potential of these organisms that serve as food borne disease vectors is of necessity. However, the exposure of garri in the market during its sale shows serious health implications especially as garri undergoes little or no cooking which could help in eliminating some of these microorganisms present in the garri before consumption.

\section{Conclusion}

According to the results obtained from this study, it can be concluded that airborne contaminants in the market areas contribute considerably to the microbial load of garri sold in market places. Also, the presence of Staphylococcus aureus and Escherichia coli in the garri samples is an indication of faecal contamination of the garri. There is therefore a need to maintain proper sanitary conditions so as to avoid health risks. The moisture content of garri samples analysed is low and within standard specification, this could have accounted for keeping the microbial load of garri low. The difference between the two brands of garri was very small indicating that both brands are good but can cause potential harm as a 
result of poor hygiene and handling. It can be concluded from this research that yellow garri is better than white garri in terms of consumption and health implication as red oil introduces Vitamin A into the garri and neutralizes its cyanide level.

\section{Recommendation}

From the findings of this research, it is necessary that the following adjustments be made to prevent contamination and to obtain the best quality of the different brands of garri sold in markets. .Garri should be sampled and stored in the market with nylon bags and transparent plastic containers which would protect the product against any infiltration of moisture, insect infestation and leakage.In large scale cassava flour processing industries, garri should not be left exposed but packaged in bags just as rice and other food products are being packaged. Packaging materials should be changed to effectively provide complete protection of the dehydrated products against moisture, light, air, dust, micro flora, foreign odour and animal pests. The packaging materials also should provide strength and stability required to maintain the original properties of products through storage, handling and marketing. Effective HACCP and GMP will help reduce or eliminate product contamination and thus make the product safe for consumption. Also, the habit of drying half fried garri on concrete, rocks, mat etc should be disallowed to reduce the level of solid particle and microbial contamination thereby preventing health hazards such as liver cancer, aspergillosis and typhoid fever. Sanitary conditions of our factories, markets and communities should be improved. Regulatory and Inspection agencies should make it a duty to educate food/garri sellers on Effective Food Handling Techniques and proper personal/environmental hygiene. This would reduce contamination from faecal origin or from handlers' skin, nose or mouth (normal flora).

\section{References}

i. Ajao, K. R. and Adegun, I. K. (2009). Performance evaluation of a locally Fabricated mini Cassava Flash Dryer. Researcher. 1 (3): $54-60$.

ii. Anastasiades, A., Thanou, S., Loulis, D., Stapatoris, A., Karapantsios, T. D. $\quad 2009 . \quad$ Rheological and Physical Characterization of Pregelatinized Maize Starches. Journal of Food Engineering. 52: 2267 - 2278

iii. Aylor, D. E., 1995. The Role of Intermittent Wind in the Dispersal of Fungal Pathogens. Annual Review of Phytopathol 28: 73 - 93 .

iv. Cheesbrough, M (2005). District Laboratory Practice in Tropical Countries CambridgeUniversityPress, Cambridge, UK. pp. 137-150.

v. Cornelia Felber, Yaoui Ouezou Azouma and Marcus Reppich 2017, Evaluation of Analytical Methods for the Determination of Physicochemical Composition of Fermented Granulated and Roasted Cassava Pulp-Garri. Food Science and Nutrition. 5(1)46-53.

vi. Eleazu C. 0 and Eleazu K. C. (2012). Determination of the Proximate Composition, Total Carotenoid, Reduced Sugars and Residual Cyanide Levels of Flours of 6 New Yellow and White Cassava Variety. American Journal of Food Technology, 7:642-649.

vii. Food and Agricultural Organization of the United Nations. (2002a). Agricultural Statistics. p 23-24

viii. Food and Agricultural Organization of the United Nations. (2002). Food and Agricultural Organic Product. FAO Rome. p 147

ix. Hartman, P., Howland, A. K. and Hahn, S. K. 2004. An Approach to Hunger and Poverty Reduction in Sub-Saharan Africa. International Institute of Tropical of Tropical Agriculture. Ibadan, Nigeria.

X. International Commission for Microbiological Specification of Food (1996). Microbiological Specification of Food Pathogens. Food Control, 7(2): 99-101

xi. Islam M. S, Hassan. M. K, and Khan S. I. (1993). Growth and survival of ShigellaFlexneri in common bangladeshi foods under various conditions of time andtemperature. Applied Environmental Microbiology. 59:652- 654.

xii. Jekayinfa, S. O. and Olajide, J. 0. 2007. Analysis of Energy Usage in the Production of Three Selected Cassava Based Foods in Nigeria. Journal of Food Engineering. 82: $217 \quad 226$

xiii. Maria, L. A. Rafael, M. R. Carolina, C. and Florencia, A. (2001). Effect of survival of Escherichia coli 0157:H7Inoculated in foods from aneotropical environment. Revision BiologicalTropics. 49(2): 517-524, 2001.

xiv. Michelet, N., Granea, P. E. and Mahillon J. 2006. Bacillus cereus Enterotoxins,bi- and tri- component cytolysins and other hemolysins. The Comparative Sourcebook of Bacterial Protein Toxins. 779-790.

xv. Nagarajan, S. and Singh, D. V. 1990. Long Distance Dispersion of Rust Pathogens. Annual Review of Phytopathol. 28:139-153

xvi. Nweke, F. I, Spencer, D. S. C and Iynan, J. K. The Cassava Press East Lansing USA 2002; 7-206.

xvii. Obadina, A. O, Oyewole, O. B., and Odubayo, M. O., (2007) Effects of Storage on The Safety and Quality of Fufu Flour. Science Research. 2:1745-1779

xviii. Ogiehor, I. S. 2002. Extension of shelf life of garri by Combination of Preservation Factors Ph. D Thesis, University of Benin, Benin- City Pp 162.

xix. Ogiehor, I. S. and Ikenebomeh, M. J. (2005). Extension of shelf life of garri by Hygienic handling and sodium benzoate treatment. African JournalBiotechnology and Microbiology. 47: 744-748.

xx. Ogiehor, I. S and Ikenebomeh, M. J. (2006). The effect of difference packaging garri. African Journal of Biotechnology. 523:2412-2416.

xxi. Ogiehor, I. S, Ikenebomeh, M. J, Ekundayo, A. O. (2007). The bioload and Aflatoxin content of market garrifrom some selected states in southern Nigeria: Public health significance. African Health Sciences. 7 (4): 223 - 
xxii. Oje, F. C., Onuegbo, J. A. and Achi, O. K. 2000. Improvement of Protein Content of garri. American Journal of Food Technology. 4: 60-65

xxiii. Omar, A. O, Mara, C. Nogueira, L, David E. G. (2003). Survival of E. coli0157:H7, Listeriamonocytogenesand Salmonella in juice concentrates. Journal of Food

xxiv. Protection. 66 (9):1595-1598.

xxv. Okolie, N. P., Brai, M. N, Atoyebi, O. M. (2012) Comparative Study on Some Selected Garri Samples Sold in Lagos Metropolis Journal of Food Studies. Vol. 1;1

xxvi. Tsav-Wau, J. A., Inyang, C. U., and Akpapunam, M. A. (2004). Microbial Quality of Fermented Cassava Flour 'Kporumilin'. International Journal of Food Science and Nutrition. 55(4) 317-324.

xxvii. Ukpabi, U. J. and Ndimele, C. 1990. Evaluation of Garri Production in Imo State Nigeria. Nigerian Food Journal. 8: 105-110

xxviii. Venugopal, M.N., Karunasagar, I. and Varadaraj, M.C. (2001). Growth and Survival of Kanagawa positive Vibroparahaemolyticus in fish and prawn Preparations held at ambient and elevated temperature. Asian FisheriesScience. 14 (200): 83-88

xxix. World Health Organizaton 1990. Environmental Health Criteria 105. SelectedMycotoxins: Ochratoxins, Truchothecenes, Ergot. World HealthOrganization, Genera.

xxx. Yngue, A. 2002. A Global Public Health Nutrition Opportunity. Public Health Nutrition 7(5): 585-589 